\title{
SOME NEW HARDY TYPE INEQUALITIES WITH GENERAL KERNELS II
}

\section{Kristina KRUlić HimmelReich AND JOSIP PEČARIĆ}

Abstract. In this paper we prove new Hardy type inequalities with general kernels. We give new results that involve the Hardy-Hilbert and the Pólya-Knopp inequality. We also prove new results that involve $n$-convex functions.

Mathematics subject classification (2010): 26D10, 26D15.

Keywords and phrases: The Hardy inequality, the Hardy-Hilbert inequality, inequalities, Hardy type inequalities, the Green function, the Taylor theorem, convex function, kernel.

\section{REFERENCES}

[1] E. K. Godunova, Inequalities based on convex functions, Izv. Vysh. Uchebn. Zaved. Matematika 47 (4) (1965), 45-53; English transl. in Amer. Math. Soc., Transl., II Ser 88 (1970), 57-66.

[2] G. H. HARDY, Notes on some points in the integral calculus LX: An inequality between integrals (60), Messenger of Math. 54 (1925), 150-156.

[3] S. Kaijser, L. Nikolova, L. E. Persson And A. Wedestig, Hardy-Type Inequalities via Convexity, Math. Inequal. Appl., 8 (2005), 403-417.

[4] S. Kaijser, L.-E. Persson, AND A. ÖBerg, On Carleman and Knopp's Inequalities, J. Approx. Theory 117 (2002), 140-151.

[5] K. Krulić, J. PeČarić, And L.-E. Persson, Some new Hardy-type inequalities with general kernels, Math. Inequal. Appl. 12 (3) (2009), 473-485.

[6] K. Krulić Himmelreich, J. PeČArić, D. Pokaz, Inequalities of Hardy and Jensen, Element, Zagreb, 2013.

[7] A. Kufner, L. Maligranda, And L.-E. Persson, The prehistory of the Hardy inequality, Amer. Math. Monthly 113 (2006), No. 8, 715-732.

[8] A. Kufner, L. Maligranda, And L.-E. Persson, The Hardy Inequality. About its History and Some Related Results, Vydavatelsky Servis Publishing House, Pilsen, 2007. 